\title{
"Nações", marcadores identitários e complexidades da representação étnica nas escritas portuguesas de viagem Guiné do Cabo Verde (séculos XVI e XVII)*
}

\section{"Nations", identity markers and complexities of ethnic representation in portuguese travel writing \\ Guinea of Cape Verde $\left(16^{\text {th }}\right.$ and $17^{\text {th }}$ centuries)}

\author{
JOSÉ DA SILVA HORTA** \\ Departamento de História e Centro de História \\ Universidade de Lisboa \\ Lisboa \\ Portugal
}

RESUMO Nas escritas portuguesas de viagem dos séculos XVI e XVII, os habitantes da Guiné do Cabo Verde, ou Grande Senegâmbia, foram claramente diferenciados por "nações". Esta diferenciação organizou o

* Artigo recebido em: 04/08/2013. Autor convidado.

** Este artigo foi originalmente apresentado na Grande Conferência realizada na Universidade Federal de Minas Gerais (UFMG) em 09/08/2013, como parte das atividades realizadas no âmbito do Programa Cátedras do Instituto de Estudos Avançados Transdisciplinares/IEAT/UFMG e patrocinado pela Fundação de Desenvolvimento da Pesquisa - FUNDEP. Agradeço ao IEAT/UFMG/FUNDEP pela bolsa concedida durante a minha permanência como Catedrático Residente. Agradeço também aos coordenadores de grupos de pesquisa, centros e laboratórios de diversas áreas do conhecimento (Letras, Artes, Ciências Econômicas, História e Educação) integrados nesta proposta transdisciplinar pelas oportunidades de debates e de projetos futuros. Agradeço, em especial, ao Departamento de História e ao seu Programa de Pós-Graduação nas pessoas dos professores Vanicléia Silva Santos e Eduardo França Paiva pelo convite, elaboração da proposta e todo o apoio durante a minha residência na UFMG. Contato: josesilvahorta@gmail.com. 
discurso dos autores e baseou-se no registro de marcadores identitários entre os quais o vestuário, o armamento e a guerra, a religião, a língua e costumes particulares. Estes e outros marcadores cruzavam questionários de origem europeia com formas oeste-africanas da percepção da identidade, a começar pela apropriação de nomes de origem local como signos identificativos das "nações". São discutidas as implicações historiográficas da interpretação da categoria de "nação", no que respeita à validade dos conceitos de grupo étnico ou identidade étnica.

Palavras-chave Guiné do Cabo Verde, "nações", identidade étnica

ABSTRACT In the 16th and 17th century Portuguese travel writing, the inhabitants of Guinea of Cape Verde, or Greater Senegambia, were clearly differentiated by "nations". This differentiation organized the authors discourse and was based in the record of identity markers, among which dressing, warfare, religion, language and particular customs, These and other markers mixed questionnaires of European origin with Western African forms of identity perception, to begin with the appropriation of names of local origin as identifiers of the "nações". The interpretation of the category of "nation" has historiographical implications, which are discussed, concerning the validity of the concepts of ethnic group and ethnic identity.

Keywords Guinea of Cape Verde, "nations", ethnical identity

Nas escritas portuguesas de viagem dos séculos XVI e XVII, os habitantes da "Guiné do Cabo Verde" (Guiné, de agora em diante) - uma região que poderíamos definir amplamente como a região entre o atual Senegal e a Serra Leoa ${ }^{1}$ - foram claramente diferenciados por "nações". Esta diferenciação entre nações baseou-se numa combinação de marcadores de identidade. Dentro da categoria geral de "escritas de viagem", uma opção conceptual que se discutiu noutro lugar, ${ }^{2}$ este artigo lida com os tratados escritos entre o final do século XVI e do século XVII, por três comerciantes portugueses, dois deles cabo-verdianos (e um destes comprovadamente mulato), que se contavam entre os chamados "práticos dos Rios de Guiné". Homens cuja perspectiva das sociedades africanas e das comunidades luso-africanas locais deve ser entendida no contexto específico de um universo sociocultural

1 Sobre a "Guiné do Cabo Verde" como categoria de representação ver HORTA, José da Silva. A "Guiné do Cabo Verde": produção textual e representações (1578-1684). Lisboa: Fundação Calouste Gulbenkian/Fundação para a Ciência e a Tecnologia, 2011, passim.

2 Ver HORTA, José da Silva. A "Guiné do Cabo Verde", Introdução e cap. 3.1. Nesta discussão, focou-se sobretudo os limites do conceito de "literatura de viagem" no contexto de uma história cultural luso-africana. 
mestiço da região a que pertenciam, universo que se designou por mundo cabo-verdiano-guineense. ${ }^{3}$ No entanto, os mesmos autores como escritores de tratados procuravam também seguir modelos discursivos ocidentais ao representarem africanos. $\mathrm{O}$ artigo argumenta que neste contexto dual podemos encontrar incongruências na forma como os critérios de distinção entre "nações" foram aplicados às sociedades africanas em causa, mas também uma recepção das lógicas oeste-africanas (ou mais precisamente do Noroeste africano, o que os historiadores anglo-saxónicos designam de Western Africa) de construção das identidades. No final discutem-se as implicações historiográficas da interpretação da categoria de "nação", para o espaço africano em questão, e para a operatividade dos conceitos que a historiografia vulgarmente designa como grupos ou identidades étnicas.

\section{Discurso antropológico 4 e escrita etnográfica}

O corpus nuclear dos relatos em causa neste trabalho é composto por descrições de terras e gentes escritas sob a forma de tratados. Seguindo as definições coevas de "tratados" e as dos próprios autores, falamos de escritos especializados que pretendem concentrar em um texto o conhecimento disponível sobre a região guineense. Dentro deste universo textual, os principais escritores que representam a nova síntese luso-africana sobre a Guiné, ${ }^{5}$ que se iniciou nos finais do século XVI, foram André Álvares de Almada (Tratado Breve dos Rios de Guiné do Cabo Verde, três manuscritos de entre 1592 e 1596), André Donelha (o "memorial" manuscrito sem título redigido em 1625) e Francisco de Lemos Coelho (Descrição da Costa de Guiné, duas versões manuscritas de 1669 e de 1684).

Estes tratados são descrições regionais sistemáticas. ${ }^{6}$ Eles podem ser considerados, com propriedade, escritos etnográficos ou etnografias na

3 Sobre este conceito ver HORTA, José da Silva. Evidence for a Luso-African identity. In: 'Portuguese Accounts on 'Guinea of Cape Verde' (Sixteenth-Seventeenth Centuries). History in Africa, v.27, p.99-130, 2000; e HORTA, José da Silva. A "Guiné do Cabo Verde".

4 Como em trabalhos anteriores, usa-se, para as antigas escritas de viagem, o conceito de discurso antropológico não como uma Antropologia enquanto disciplina no sentido em que foi definida a partir do século XIX, mas enquanto discurso sobre o Homem, tantas vezes associado à vertente geográfica nessas escritas. Ver por outros HORTA, José da Silva. A representação do africano na literatura de viagens, do Senegal à Serra Leoa (1453-1508). Mare Liberum. Revista de História dos Mares, Lisboa, n.2, p.209-339, 1991.

5 Como se desenvolveu nos trabalhos citados nas notas anteriores esta nova síntese luso-africana distingue-se das primeiras descrições de toda a costa da Guiné datadas do início do século XVI - referimo-nos às de Valentim Fernandes e de Duarte Pacheco Pereira (entre 1505 e 1508) - pelo novo contexto de relacionamento que envolveram e portanto de representações, mais de um século passado sobre as primeiras presenças portuguesas na região. É o maior aprofundamento dessas relações, e a natureza dos textos, que justifica a opção pelo corpus textual deste estudo.

6 Pormenorizou-se a definição de escrita tratadística em HORTA, José da Silva. A Guiné do Cabo Verde, caps. 3.1 e 3.2. Um conceito semelhante de "sistemática descritiva" (antropológico-geográfica) é utilizada para época próxima e diferentes espaços alvos de escrita por BARRETO, Luís Filipe. A ordem do saber na antropologia dos descobrimentos portugueses. In: A ciência e os descobrimentos. s.I.: Junta Nacional de Investigação Científica e Tecnológica, 1996, p.25-67; e RUBIĖS, Joan Pau: "the systematic geographical compilation with economic and ethnological information for official and semi-official purposes"; Giovanni di Buonagrazia's letter to his father concerning his participation in the second expedition of Vasco da Gama (1502-1503), Mare Liberum, Lisboa, n.16, 
medida em que os autores descrevem povos e explicitamente têm a intenção de o fazer como uma parte importante dos seus trabalhos. ${ }^{7}$ No caso de André Álvares de Almada estamos perante um caso raro, pelo menos para o Noroeste Africano dos séculos XVI e XVII, ${ }^{8}$ no sentido em que temos, literalmente, uma monografia etnográfica, um livro que se centra na descrição de "nações", povos ou grupos étnicos (correspondência conceptual discutida adiante). O seu escrito e o seu discurso antropológico, apesar de seguir uma sequência geral da costa e das ilhas segundo uma ordem geográfica - Norte-Sul -, não está submetido ao discurso geográfico. Pelo contrário, foi sistematicamente organizado por povos e reinos, mas os primeiros não estão necessariamente subordinados aos segundos, apesar de ser observável que constituem um par temático recorrente. Veja-se, logo a abrir o manuscrito da Biblioteca Pública Municipal do Porto, datado de 1594 - o mais conhecido e esteticamente apurado para uma possível impressão, que nunca ocorreu no seu tempo - o título do primeiro capítulo: "Que trata dos negros Jalofos (i.e. os Wolof), que são os primeiros chegados a nós, e dos seus costumes e trajos (cancelado "leis" - em vez de "trajos" - que tinha sido a opção no manuscrito de Lisboa, anterior)". ${ }^{9}$ Esse título é semelhante a outro de André Donelha que vai no mesmo sentido "'Da lei e costumes dos Jalofos e o que aí se resgata" (cap. 9). ${ }^{10}$ Donelha, escrevendo um relato mais sintético,

p.87-112, dezembro 1998 e aplicado por LOUREIRO, Rui - que os designa por "tratados etno-geográficos"-Visões da Ásia (séculos XVI e XVII). In: CRISTOVÃO, Fernando (coord.). Condicionantes culturais da Literatura de Viagens. Estudos e bibliografias. Lisboa: Edições Cosmos, Centro de Literaturas de Expressão Portuguesa da Universidade de Lisboa, 1999, p.337-353, p.347 (reimpressão, Almedina, 2002).

7 Sobre este conceito de Etnografia e outras categorias de discurso derivadas, ver a clarificação de MASON, Peter. The ways of the World: European representations of other cultures from Homer to Sade. Hereford: Sean Kingston Publishing, cap.2 (no prelo)

8 Poderíamos encontrar semelhanças em textos jesuítas do início do século XVII sobre a região e dentre eles sobretudo no tratado do Padre Manuel Álvares, Etiópia Menor e Descripção Geographica da Província da Serra Leoa (c.1615, cópia do século XVIII), manuscrito da Sociedade de Geografia de Lisboa, Res. 3 E-7, inédito em versão portuguesa, traduzido em inglês por P. E. H. Hair, em publicação com as suas anotações inéditas, edição com nova transcrição do texto português coordenada pelo autor deste estudo e por Maria Manuel Ferraz Torrão. No entanto, esses textos tiveram como ponto de partida a leitura (direta ou indireta em resumo) de um terceiro manuscrito, abreviado, do tratado de Almada, o Cód. 525 da Biblioteca Nacional de Portugal de c. 1596 ou, então, as informações escritas ou orais colhidas entre os comerciantes "práticos" dos "Rios de Guiné". A análise do grande contraste discursivo sobre as "nações" na Etiópia Menor não cabe no espaço deste artigo.

9 ALMADA, André Álvares de. Tratado breve dos Rios de Guiné do Cabo Verde des do Rio de Sanaga ate os baixos de Santa Anna de todas as nações de negros que ha na ditta costa e de seus costumes armas trajos juramentos g(u)erras feito pelo capitão Andre Alvares d' Almada natural da llha de Santiago de Cabo Verde pratico, e verçado nas ditas partes. Año 1594: Biblioteca Pública Municipal do Porto, Ms. 603. Publicado por BRÁSIO, António. Tratato breve dos Rios de Guiné do Cabo Verde. Lisboa, Editorial L.I.A.M., 1964 (doravante Almada. Tratado), p.5. Trata-se do joeiramento e recomposição de uma versão ligeiramente anterior (de que alguns excertos foram acrescentados em nota à edição de Brásio), inédita na sua publicação integral, intitulado Tratado breve dos Reinos de Guiné do Cabo Verde feito pollo capitão Andre Allvares d'Allmada natural da cidade e ilha do Cabo Verde cursado e pratiq(u) o nas ditas partes: Biblioteca Nacional de Portugal (doravante BNP), Cód.297, fls.1-109, datável de c.1592-1593. Os dois primeiros capítulos acima referidos aparecem fundidos num só, entre as folhas 2v. a 18v. do Cód. 297 da BNP.

10 DONELHA, André (Santiago), 1625: Biblioteca da Ajuda, cód. 51-IX-25, (n.39), 35fls, publicado sob o título de Descrição da Serra Leoa e dos Rios de Guiné do Cabo Verde (1625) por Avelino Teixeira da Mota; notas de Teixeira da Mota e de P. E. H. Hair, trad. inglesa de P. E. H. Hair, Lisboa, Junta de Investigações Científicas do Ultramar, 1977, p.128. É de notar que a historiografia não conseguiu estabelecer qualquer relação intertextual entre os escritos de André Donelha e de André Álvares de Almada. Até prova em contrário, Donelha não terá sido um leitor de Almada, o que não significa que não tenha, muito possivelmente, privado e dialogado com ele, membro que era do pequeno meio mercantil da ilha de Santiago de Cabo Verde, em que foram conterrâneos. 
tratou, neste caso, apenas o "reino dos Jalofos", o antigo Grão-Jolof, ou a confederação de unidades políticas tributárias do rei do Jolof (o buurba-jolof), entre o rio Senegal e o rio Gâmbia, e as circunstâncias que envolveram a sua desagregação (no século XVI) ${ }^{11}$ - bem mais pormenorizado em Almada - bem como os seus costumes, apenas mencionando em algumas linhas o "reino dos Berbesins". Já Almada, no mesmo capítulo, tratou também do "Grão-Fulo" (o Fuuta-Tooro) ${ }^{12}$ e dos Fulas; tema que retomou e imbricou no capítulo seguinte "Dos mais costumes dos Jalofos" (este resultado da fusão, num só, de dois capítulos do manuscrito de Lisboa) e estabeleceu comparações, por exemplo, entre regras de hereditariedade vigentes entre "os mais Reinos dos Jalofos, Mandingas (e) Barbacins" ou entre costumes alimentares de wolof e mandingas. ${ }^{13}$

Na verdade, Almada apercebeu-se do que designaríamos hoje de dinâmicas da etnicidade, não rigidamente submetidas à organização do espaço em unidades políticas: as relações entre as "nações" foram vistas como algo de dinâmico, como uma tensão e complementaridade permanentes, ao mesmo tempo que enquadradas por uma visão integradora do espaço político. ${ }^{14}$ Esse fato fê-lo por vezes misturar, de forma algo incongruente aos olhos do historiador atual, noções hidrográficas, mercantis, políticas e culturais num título de capítulo como "Que trata do Reino de Gâmbia (nome de rio), chamado por outro nome de Cantor (nome de porto fluvial de referência), que é o Reino dos Mandingas, mui grande em si" (cap. 5) ou então mesclar no mesmo título o critério político e cultural "Que trata do Reino do Borçalo (buur-saalum), que são Jalofos e Barbacins e do mais que nele há" (cap. 4). ${ }^{15}$ Enquanto Donelha incluiu com alguma frequência os nomes das nações e reinos nos títulos dos capítulos, já a mais tardia descrição de Francisco de Lemos Coelho, sobretudo preocupado em escrever um roteiro mercantil, tal situação foi mais rara, optando por privilegiar nos títulos (e no relato) a sequência fluvial e portuária ou os dados hidrográficos em geral. Em contrapartida, o mesmo Lemos Coelho apresentou, no final da descrição de 1669, uma listagem sistemática, sob a forma de esquema, dos reinos de cuja existência ele tinha informação (incompleta como ele próprio

11 Sobre os reinos wolof e a sua história ver, por outros trabalhos de BOULÈGUE, Jean. Les royaumes wolof dans l'espace sénégambien (XIIle-XVIIIle siècle), Paris: Éditions Karthala, 2013. Para uma visão mais pormenorizada até ao século XVI, ver BOULĖGUE, Jean. Le Grand Jolof (XIIle-XVle siècle). Blois-Paris: Façades, Karthala, 1987.

12 Sobre as relações entre os territórios dos wolof e dos fulas do Fuuta-Tooro, ver também, KANE, Oumar. La première hégémonie peule: le Fuuta-Tooro de Koli Tenella à Almaami Abdul. Paris/Dakar: Karthala/Presses Universitaires de Dakar, 2004

13 ALMADA. Tratado, p.20-21 e passim.

14 Ver HORTA, José da Silva. O nosso Guiné: representações luso-africanas do espaço guineense (sécs. XVI-XVII). Actas do Congresso Internacional "O Espaço Atlântico de Antigo Regime: poderes e sociedades". Instituto de Investigação Científica Tropical e Centro de História de Além-Mar, 2009, publicado em Cd-Rom e on-line, na Biblioteca Digital Camões. Disponível em: <http://www.instituto-camoes.pt/cvc/eaar/coloquio/comunicacoes/ jose silva horta.pdf $>$. Acesso em: 22 jul. 2013.

15 ALMADA. Tratado, p.43 e p.32. 
confessa), organizados segundo as "nações" neles dominantes (não sem equívocos da sua parte). ${ }^{16}$

Estamos em crer que nos critérios de titulação e, portanto, de organização do tratado de Almada, se verificou uma tensão entre, por um lado, o conhecimento empírico que ele obteve na sua vizinha ilha de Santiago de Cabo Verde, população insular maioritariamente de origens guineenses, de que, tal como Donelha, pertencia à elite mercantil, maioritariamente mestiça, e sobretudo no decorrer das contínuas viagens que fez à costa africana, e, por outro, o modelo europeu e português de caracterização das "nações" que tenderia a atribuir uma correspondência entre um território e um reino/ rei e um povo ou nação. ${ }^{17}$ No entanto, quando tal correspondência não se verificava, o que prevaleceu foi o conhecimento, de experiência própria e alheia feito, a que adaptou a descrição. Escrevendo mais tarde, fruto de um know-how acumulado, encontramos um maior número de unidades políticas referidas por Lemos Coelho referidas a uma mesma "nação" ou "casta" (ver adiante).

O livro de Almada foi também aquele cujo título revelou e sintetizou afigura-se, aliás, um título-sumário -, os principais tópicos ou categorias de informação típicas dos tratados em análise. Para cada "Reino e Nação"18 ou mais em geral comparando duas, três ou mais nações, ele pretendia - tal como afirma - tratar: "seus costumes, armas, trajos, juramentos, guerras". O seu objecto foi clarificado e ampliado no Prólogo do manuscrito do Porto incluindo "linguagens", "seitas e costumes e as leis do seu (dos "negros") governo e juramentos" e "de tudo o mais que nas ditas partes é notável". Sabemos que aqui inclui "as cousas notáveis que entre eles se passaram", isto é, a sua História, consoante os cânones de escrita antropológico-geográfica da época. ${ }^{19}$ Como já se viu, nos títulos dos capítulos sublinhou frequentemente alguns destes tópicos, "leis e costumes", "costumes", "guerras" etc. Todavia não mencionou explicitamente a descrição do comércio dessas nações como um dos seus alvos. Se lhe deu grande ênfase na economia

16 Ver COELHO, Francisco de Lemos. Descripção da Costa de Guiné desde o cabo Verde athe a Serra Lioa com todas as ilhas e rios a que os brancos assistentes nella navegão (1669), Cód.307 da BNP ed. por PERES, Damião. Duas descrições seiscentistas da Guiné de Francisco de Lemos Coelho. Lisboa: Academia Portuguesa da História, 1990, p.84-8 (doravante LEMOS COELHO. Descripção (1669)). A lista é alvo de generalizações várias que não resistem ao confronto com os outros dois tratados em análise. Uma delas é ignorar a existência de uma população sereer maioritária nos reinos do Siin ("Berbesim") ou relevante no do Saalum ("Borsalo") que o autor subordinou ao título "Reynos Jalofos".

17 Sobre esse modelo, ver MATOS, Sérgio Campos. Nação. Ler História, n.55, p.111-24, p.111-2, 2008; HOPPENBROUWERS, Peter. Medieval peoples imagined. In: BELLER, Manfred; LEERSSEN, Joep. (eds.). Imagology: the cultural construction and literary representation of national characters, a critical survey. Amsterdam/New York: Rodopi, 2007, p.50-51; LEERSSEN, Joep. The poetics and anthropology of national character (1500-2000). Imagology, p.64. A perspectiva do presente estudo distancia-se parcialmente da "Imagology" - "analysis of national stereotypes in literature (and in other forms of cultural representation)" (LEERSSEN, Joep. Forward, p.xiii) - no sentido em que, ao contrário daquele campo de investigação, a análise de representações assume-se neste artigo como uma via necessária para compreender as sociedades alvo do discurso e não apenas este por si próprio.

18 ALMADA. Tratado, p.2-3

19 Ver HORTA, José da Silva, A Guiné do Cabo Verde, cap.3.3, em que se sublinhou o recurso às tradições orais africanas para se satisfazer esse cânone. 
da escrita e são uma constante da descrição, tal com nos outros tratados, só nos manuscritos de Lemos Coelho o comércio, nomeadamente com os portugueses, é assumido como o grande foco da escrita. ${ }^{20} \mathrm{O}$ conceito de "costumes" é bastante lato, tanto incluindo comportamentos, que podiam ser alvo ou não de avaliação moral, como todo o tipo de atividades, específicas ou partilhadas por diferentes "nações". ${ }^{21}$ "Juramentos" constituiu uma denominação única em Almada por comparação com os outros tratados ${ }^{22}$ e merece que, por isso, nos detenhamos brevemente nela.

Nas escritas de viagem sobre a Guiné, a menção do juramento aparece no início do século XVI na Descripçam do morávio Valentim Fernandes uma única vez, a propósito dos Banhuns (Bainunk), cujo informador compreendeu como ele era levado a sério e temido. ${ }^{23}$ Como é sabido, tal com o Esmeraldo de Duarte Pacheco Pereira, ${ }^{24}$ a obra de Fernandes não foi publicada no seu tempo e pouco circulou em manuscrito, nem há relações intertextuais detectáveis com os tratados posteriores, apesar da semelhança de alguns tópicos que organizam os discursos. Almada alude numerosas vezes aos "juramentos" em uso nas "nações", mencionando se são ou não comuns entre elas e a importância que têm, o que justifica aparecerem explicitados como classe de informação. Aparecem associados sobretudo a formas de julgamento ou de "juízo", apuramento da verdade selado com um ritual e com a invocação, nem sempre clara para o autor, de entidades sobre-humanas. ${ }^{25}$

Sublinha-se a preocupação frequente de Almada e dos outros autores em estabelecer denominadores comuns entre diferentes "nações" na religião, nos costumes, na justiça, e noutras classes de informação. Contrastando com uma abordagem mais individualizada das nações da Europa, tal resultava, novamente, de uma constatação ou dir-se-ia mesmo, de uma imposição empírica de uma realidade específica e distinta. Ouçamos Almada:

E como os reinos dos negros sejam tantos e as linguagens tão várias como os costumes diversos, porque em cada espaço em menos de vinte léguas há duas

20 Bastará ver a regularidade da presença deste tópico nos títulos dos capítulos das duas versões, de 1669 e de 1684

21 Neste sentido diferem da separação entre "costumes" e "práticas" numa obra coeva do mesmo tipo, como o Itinerario de Jan Huygen van Linschoten. Ver BOOGAART, Ernst van den. Civil and corrupt Asia: image and text in the itinerario and the icones of Jan Huygen van Linschoten. Chicago/London: The University of Chicago Press, 2003, p.10.

22 Os "juramentos" vão aparecer com classe de informação em relatos não portugueses posteriores que incluiram a região da Guiné do Cabo Verde, como por exemplo o de Jean Barbot ("oaths"). Ver BARBOT, Jean. Barbot on Guinea: the writtings of Jean Barbot on West Africa 1678-1712. Editado por HAIR, P. E. H.; JONES, Adam; LAW, Robin; P. E. H. HAIR. 2 vols, v.1. London: The Hakluyt Society, 1992, p.84, p.261 (para territórios do golfo da Guiné, v.2, p.570, p.634).

23 FERNANDES, Valentim. A descripçam de Cepta por sua costa de Mauritania e Ethiopia pellos nomes modernos prosseguindo as vezes alguas cousas do sartão da terra firme (doravante FERNANDES. Descripçam) pub. In: Códice Valentim Fernandes, leitura paleográfica, notas e índice (de) José Pereira da Costa. Lisboa: Academia Portuguesa da História, 1997, p.95-96. A redação do corpo principal da descrição é datada pelo próprio autor de 1507.

24 PEREIRA, Duarte Pacheco. Esmeraldo de Situ Orbis de Duarte Pacheco Pereira (Édition critique et commentée), por Joaquim Barradas de Carvalho. Lisboa: Fundação Calouste Gulbenkian,1991.

25 ALMADA. Tratado, por exemplo o juramento "da água vermelha" entre os Cassangas, p.65-66 e entre os Banhuns, p.84. 
e três nações, todas misturadas, e os reinos uns pequenos, e outros grandes, sujeitos uns aos outros, e como suas seitas e costumes e as leis do seu governo e juramentos venham, pela maior parte, a ser todos uns, não será necessário fazer declarações (nem) particular menção, porque de todos direi geralmente. ${ }^{26}$

E novamente, na versão do manuscrito de Lisboa, a propósito do reino de Kasa ou Casamansa:

Muitas vezes quando neste Rio (Casamansa) estauão os nossos apouzetados nas alldeias cõ os negros juntamente, não se segurauão sem o Rei fazer primeiro este juramento, o qual fazia todos os anos; este juramento fazẽ os Banhũs, Buramos chamados por outro nome Papeis e os Chãos, $\widetilde{q}$ todas estas nasões estão misturadas; chamo juntas porque se entendem hũas cõ as outras, mas as terras estão diuididas e os Reinados. ${ }^{27}$

Note-se que, nestes relatos, tanto eram classificados como "nações", as várias africanas, assim como as europeias com atividades mercantis na região, os Portugueses, os Franceses, os Ingleses ou, a partir do início do século XVII, também os Holandeses. ${ }^{28}$ Ao caracterizar as relações euroafricanas na costa do atual norte do Senegal na segunda metade do século XVII, Lemos Coelho não podia ser mais claro: "Os negros são muito amigos dos Portuguezes, mais que de qualquer outra nação; os da beira mar, os mais delles, fallão a nossa lingoa e a flamenga e franceza". ${ }^{29}$ Os autores procuravam transmitir por comparação e analogia o que observavam com as categorias disponíveis no seu stock cultural (Edgar Morin). A forma como o faziam, particularmente patente nas duas citações de Almada, distanciavaos do que designaríamos hoje de uma visão rígida e fechada das identidades étnicas tão criticada pela corrente dinamista da Antropologia, esta marcada por uma visão anti-essencialista das culturas. ${ }^{30}$

Apesar das confusões em que poderia cair na identificação das "nações" em causa, aquelas palavras do autor cabo-verdiano refletiam, a seu modo, a fluidez e a flexibilidade que caracterizavam o que pode ser teorizado como um modelo de construção identitária próprio a toda a região da Guiné ou Grande Senegâmbia (doravante Senegâmbia) e com nexos

26 ALMADA. Tratado, p.2. O grifo é nosso.

27 ALMADA, Cód.297 da BNP extraído em nota por BRÁSIO, António. Tratado, p.84. O grifo é nosso.

28 Ver DONELHA. Descrição, p.102. Os Holandeses aparecem também referidos por Donelha e Lemos Coelho por "Framengos" (Flamengos).

29 COELHO, Francisco de Lemos. Discripção da Costa de Guiné e situação de todos os portos, e rios della; e roteyro para se poderem navegar todos seus rios (1684). BNP, Cód.454, ed. por PERES, Damião. Duas descrições seiscentistas da Guiné de Francisco de Lemos Coelho. Lisboa: Academia Portuguesa da História, 1990, p.89-250 (doravante LEMOS COELHO. Discripção (1684)), p.100-101.

30 Ver a síntese desta visão por AMSELLE, Jean-Loup. Ethnies et espaces: pour une anthropologie topologique. In: AMSELLE, Jean-Loup; M'BOKOLO, Elikia. (eds.). Au coeur de l'ethnie: ethnies, tribalisme et état en afrique. 2 ed. Paris Éditions La Découverte/Poche, 1999 (1 $1^{\mathrm{a}}$ ed. 1985), p.11-48, sem esquecer a retificação das posições do autor no novo prefácio desta edição com M'Bokolo. Ver também de AMSELLE, Jen-Loup. Mestizo logics: Anthropology of identity in Africa and elsewhere. Stanford: Stanford University Press, 1998 ( $1^{\mathrm{a}}$ ed. francesa 1990), principalmente a Introdução e os caps.1-3. 
com o arquipélago de Cabo Verde. ${ }^{31}$ Numa transversalidade marcada pelos interesses mercantis comuns, a definição da identidade baseava-se na convivência, na negociação, na assunção da dualidade ou pluralidade de identidades conforme as circunstâncias e não na definição de fronteiras claras entre grupos. ${ }^{32}$ A estratégia discursiva dos tratadistas encontra um primeiro esboço nas primeiras descrições gerais da costa ocidental de África do início do século XVI, entre 1505 e 1508, a Descripçam de Valentim Fernandes e o Esmeraldo De Situ Orbis de Duarte Pacheco Pereira. Nelas proliferam aquilo que poderíamos designar etnônimos como signos identificativos das populações e os parâmetros da representação deixam de ser marcados, em exclusivo, pelo confronto/comparação/analogia com a realidade portuguesa ou europeia mas também pela comparação entre sociedades africanas. ${ }^{33}$

\section{O que era uma "nação"? Marcadores identitários e lógicas oeste- africanas}

Esta diferenciação entre diferentes "nações" de Negros - este o signo corrente de identificação dos Africanos em geral - era baseada numa combinação de marcadores de identidade. A cor da pele ou outros aspectos somáticos são escassamente usados pelos autores para estabelecer essa diferenciação, reservados para casos particulares. Na verdade, apenas ma-

31 Ver numerosas contribuições que, apesar das suas especificidades, têm confluído para pensar esse modelo: MARK, Peter. A cultural, economic, and religious history of the Basse Casamance since 1500. Stuttgart: Frobenius Institute \& Steiner Verlag, 1985; BARRY, Boubacar. La Sénégambie du XVe au XIXe siècle: traite négrière, Islam et conquête coloniale. Paris: Éditions l'Harmattan, 1988; TRAJANO FILHO, Wilson: Polymorphic creoledom: the "Creole" society of Guinea-Bissau. University of Pennsylvania, 1998 (Antropologia, Tese de doutorado), trabalho desenvolvido em vários artigos posteriores; BARRY, Boubacar. Senegâmbia: o desafio da história regional. Amsterdão/Rio de Janeiro: SEPHIS (South-South Exchange Programme for Research on the History of Development)/ Centro de Estudos Afro-Asiáticos (Universidade de Cândido Mendes), 2000; MARK, Peter. Portuguese'style and Luso-African identity: precolonial Senegambia, sixteenth-nineteenth centuries. Bloomington: Indiana University Press, 2002; HORTA, José da Silva. For a Luso-African identity in 'Portuguese' accounts on 'Guinea of Cape Verde' (XVle-XVIle siècles). History in Africa, v.27, p.99-130, 2000; HAVIK, Philip J. Silences and soundbytes: the gendered dynamics of trade and brokerage in the pre-colonial Guinea Bissau region. Münster: Lit Verlag, 2004; HORTA, José da Silva. Ser 'Português' em terras de Africanos: vicissitudes da construção identitária na 'Guiné do Cabo Verde' (sécs. XVI-XVII). In: HORTA, José da Silva et al. (eds.). Nação e identidades - Portugal, os portugueses e os outros. Lisboa: Centro de História, Caleidoscópio, 2009, p.261-273. DIAS, Eduardo Costa; HORTA, José da Silva. Sénégambie: un concept historique et socioculturel et un objet d'étude réévalués", Trade, Traders and CrossCultural Relationships in Greater Senegambia, número especial da revista Mande Studies, University of Wisconsin/ Madison, 2007 (2010), p.9-20; MARK, Peter; HORTA, José da Silva. The forgotten Diaspora: Jewish communities in West Africa and the making of the Atlantic World. Cambridge: Cambridge University Press, 2011 (especialmente nos caps. 2 e 6); GREEN, Toby. The rise of the Trans-Atlantic slave trade in Western Africa, 1300-1589. Cambridge: Cambridge University Press, 2011; HORTA, José da Silva. A “Guiné do Cabo Verde”. Para as ligações com Cabo Verde, ver HORTA, José da Silva. Evidence for a Luso-African identity; SANTOS, Maria Emília Madeira Santos et al. Cabo Verde: uma experiência colonial acelerada (séculos XVI-XVII). Porto: Universidade Portucalense/Arquivo Histórico Nacional de Cabo Verde, 2001, separata de Africana, Porto, n.6, p.49-78; HORTA, José da Silva. A “Guiné do Cabo Verde"; GREEN, Toby. Building Creole identity in the African Atlantic: boundaries of race and religion in 17th-Century Cabo Verde. History in Africa, v.36, p.103-125, 2009.

32 Ao contrário do que defende a perspectiva clássica de BARTH, Fredrik. Ethnic groups and boundaries. In: Selected essays of Fredrik Barth, v.1: Process and form in social life. London: Routhedge \& Kegan Paul Ldt., 1981, p.198-227.

33 Estes e relatos anteriores foram tratados em HORTA, José da Silva. A representação do africano na literatura de viagens, do Senegal à Serra Leoa (1453-1508). 
tizes cromáticos e aspectos físicos que se distinguiam das restantes nações de "Negros" justificavam essa referência. Tal ocorre como um dos traços distintivos dos Fulas nos escritos de Almada $^{34}$ e de Lemos Coelho, coincidindo na "cor amulatada". Vejamos alguns excertos da descrição do primeiro:

E estes Fulos são deles homens robustos bem dispostos, ${ }^{35}$ a cor amulatada, os cabelos corredios, e ainda que algum tanto crespos, trazem as barbas crescidas; usam na paz e na guerra as mesmas armas das que usam os Jalofos, e os mesmos vestidos. São mui guerreiros; fazem guerra algumas vezes aos Jalofos (...).Usam grandemente de gente frecheira de cavalo. Prezam-se de suas pessoas; falam com voz de papo, como quem gagueja; tem o sal muita valia na terra destes, mais que outra mercadoria nenhuma; e algum que lhe(s) vai é por via dos Mandingas do rio de Gâmbia, donde o fazem, e dos Jalofos de Sanagá. E o não podem comprar senão o Rei, ou Senhores das terras sòmente, nem o comem todos, senão os grandes e suas mulheres e filhos. E se dá a troco dele ouro, escravos, panos finos, e o mais que querem. Entram estes Fulos por toda aquela terra da costa dos Jalofos, Barbacins e Mandingas, com suas criações e gados; (...). É verdade que (o rio Senegal) também tem no inverno suas venidas e crescentes, pela muita água que lhe chove no seu nascimento; das quais crescentes deu Nosso Senhor indústria e saber a estes Fulos brutos, para usarem nas suas searas e lavouras (...).

Estes Fulos deste sertão, vendo a um dos nossos, pasmam pelos verem brancos, sem embargo de eles não serem negros.

O comentário final, parece remeter para a observação de um lusoafricano ("um dos nossos") mulato, o que nos levaria longe na contextualização deste passo. Lemos Coelho referia-se à beleza das mulheres fulas ("bem parecidas"), tal como, mas sem referência cromática, Donelha ao bom aspecto físico dos Bolões da Serra Leoa ("bem apessoados). ${ }^{36}$ Por contraste, mas sem juízo de valor detectável, no mesmo Almada, aparece a referência a "preto", como sinônimo, assim expresso, de "muito negro", respectivamente na caracterização de Felupes e de Buramos e de "mui pretos" para os Bijagós (na região da atual Guiné-Bissau) (77 $^{37}$ numa situação abaixo mencionada para Fulas. Os três autores nada mais mencionam a este respeito ao longo dos seus escritos sobre as múltiplas nações elencadas: os aspectos tantas vezes incorretamente referidos pela historiografia das relações afro-portuguesas como "raciais" ou de "raça" constituíam um

34 Rogério Puga não notou os aspectos somáticos como particularmente relevantes na descrição dos povos no seu estudo sobre o texto de Almada, o que confirma as nossas conclusões. Ver PUGA, Rogério Miguel. O discurso (Etnográfico) da alteridade no Tratado Breve dos Rios de Guiné do Cabo-Verde (1594) do Capitão André Álvares de Almada. Actas do Congresso Internacional "O Espaço Atlântico de Antigo Regime: poderes e sociedades". Instituto de Investigação Científica Tropical e Centro de História de Além-Mar, 2009, publicado em Cd-Rom e on-line na Biblioteca Digital Camões. Disponível em http://cvc.instituto-camoes.pt/eaar/coloquio/comunicacoes/ rogerio_miguel_puga.pdf. Acesso em: 22 jul. 2012.

35 Almada tinha escrito anteriormente dos Wolof ("Jalofos") que eram também "bem dispostos" mas "enxutos". ALMADA. Tratado, p.12.

36 LEMOS COELHO. Descripção (1669), p.8; DONELHA. Descrição, p.100

37 ALMADA. Tratado, p.61, p.79, p.91. 
marcador identitário de menor importância na descrição das "nações"; daí não admirar a sua ausência nos tópicos que pretendiam focar. A tal não será estranho o facto das culturas africanas locais terem as suas próprias representações da cor da pele, cujo significado remetia mais para a profissão e estatuto social do que para a pigmentação. ${ }^{38} \mathrm{Em}$ contrapartida, no corpo visto, como um todo, enquanto primeiro interface entre duas entidades que se encontram (perspectiva de Vanessa Thomas), o corpo cultural era bem mais importante que o corpo somático ${ }^{39}$ como marcador distintivo na óptica dos autores. A descrição acima citada não esgota os materiais de Almada sobre os Fulas, como é o caso da distinção, dentre eles, dos "Fulas pretos" 40 que viviam entre os Wolof e que tinham origem na região do FuutaTooro, antigo Takrûr, acima do Waalo, no vale do rio Senegal (designa-os de "Tucurois", tal como já consta em 1505-1508 no Esmeraldo de Situ Orbis de Duarte Pacheco Pereira, e "Tucuroes", pelos mesmos anos, na Descripçam de Valentim Fernandes, que vinham do etnónimo wolof Tukulër, mais tarde metamorfoseado no francês Toucouleurs $)^{41}$ e cumpre em grande parte o programa temático de caracterização das "nações" a que se tinha proposto.

É importante, neste ponto, compreender que a categoria europeia de nação, acompanhada pelos autores, derivava, por via do Latim, de nascimento, de origem comum. ${ }^{42}$ Nesse sentido, mantinha uma relação próxima, quando não mesmo sinonímica, com outras categorias do mesmo campo semântico: "casta" e "raça". "Raça" não consta nos tratados com esse sentido; "casta" sim, mas não tem o sentido indiano, já percepcionado nos primeiros relatos portugueses daquele subcontinente asiático. ${ }^{43} \mathrm{O}$ termo "casta" é aplicado por analogia com uma metáfora do reino animal ou vegetal para expressar uma mesma origem genealógica (que na etimologia remetia para a pureza dessa

38 O autor, em conjunto com Peter Mark, criticou recentemente a tendência historiográfica referida e a necessidade de valorizar os pontos de vista africanos acerca de supostas diferenciações raciais, analisando o caso da Senegâmbia do século XVII. HORTA, José da Silva; MARK, Peter. Towards a revision of "racial" thought in early Afro-Portuguese relationships: the case of the Senegambian Jewish communities and their connection with Amsterdam in the 17th century. Comunicação inédita apresentada à $5^{\text {th }}$ European Conference on African Studies. African dynamics in a multipolar World, Lisboa, 26/29 de Junho de 2013. A questão da representação oeste-africana da cor da pele para o período que interessa a este estudo foi abordada por estes autores noutros estudos. Ver supra, nota 30.

39 Para esta concepção do corpo, mas para o período dos primeiros contatos afro-europeus em que o corpo somático ganhou um espaço significativo, ver o trabalho inovador de THOMAS, Vanessa. Représentations européennes des corps africains au cours des permiers contacts sur les rives atlantiques (1341-1508): le passage du mythe à la construction du réel par l'expérience vécue. Lisboa: Faculdade de Letras da Universidade de Lisboa, 2013 (História, Dissertação de mestrado). Para o corpo somático nesse período ver também HORTA, José da Silva. A representação do africano na literatura de viagens, cap.1.

40 ALMADA. Tratado, p.11.

41 BOULĖGUE, Jean. Le Grand Jolof, p.22. Mas ver a forma correta da transcrição do etnônimo, "Tucuroes", em FERNANDES, Valentim. A descripçam, p.88.

42 Ver por outros: KEMILÄINEN, Aira, Nationalism: problems concerning the word, the concept and classification. Jyräskyl: Kunstantajat Publishers, 1964, p.13 e ss.; HROCH, Miroslav; MALEČKOVÁ, Jitka. "Nation"; a survey of the term in European languages. In: LEDUSSI, Athena (ed.). Encyclopedia of Nationalism. New Brunswick: Transaction Pub. 2000, p.203-208; CHIARAMONTE, José Carlos. Metamorfoses do conceito de nação durante os séculos XVII e XVIII. In: JANCSÓ, István (org.). Brasil: formação do Estado e da Nação. São Paulo: Hucitec/Ed. Unijuí/Fapesp, 2003, p.61-91, p.66 e p.85-86. Agradeço a Sérgio Campos Matos o acesso a estas publicações.

43 RUBIÉS, Joan-Pau. Travel and ethnology in the Renaissance: South India through European eyes, 1250-1625 Cambridge: Cambridge University Press, 2002 (1ª ed. 2000), p.202. 
origem). Uma significação e processo analógico ocorria também com "raça". Note-se que o termo "raça" estava em pleno uso na época, fazendo, por exemplo, parte do léxico corrente da Inquisição portuguesa e das avaliações da "limpeza do sangue" necessária para acesso a determinados cargos e dignidades mas não tinha uma conotação que hoje se diria racial. ${ }^{44}$ Remetia para a origem (raiz) familiar, quer étnica, quer religiosa. Neste sentido, poderia ter um uso semelhante ao do conceito de "nação". Assim, na documentação da época, tanto se falava que um indivíduo era "jalofo de nação", "de raça jalofo", como um outro era "de raça moura (no sentido de muçulmano)" ou "mouro de nação". Nos tratados que analisamos o termo alternativo a "nação" era o de "casta". Muito menos presente em Almada, ${ }^{45}$ está ausente em Donelha, mas é muito frequente em Lemos Coelho, a ponto de "nação" e "casta" serem indiferentemente usados. Neste, por exemplo: "casta de negros que chamão Jagancazes" (Jakanké)" - ou usando a mesma fórmula, que remete para um conhecimento corrente dos etnônimos na Guiné -, "casta de negros que chamão de Xéreos" (Sereer). ${ }^{46}$ Na versão de 1684 do seu tratado, "nação" e "casta" foram usados em passos diferentes para classificar este último grupo. ${ }^{47}$

Numa consulta sobre a "nomeação de pessoas para o cargo de "cappitam de Cacheo", dada em Lisboa, a 17 de Julho de 1632, diz-se sobre um dos candidatos que não tinha "raça alguã de nação infesta" ${ }^{48}$ A referência era sobretudo para a "nação" dos judeus e cristãos-novos. Nos espaços de presença colonial portuguesa, os cristãos-novos tinham um lugar à parte - negativo - nesta classificação, o que não sucedia necessariamente com as origens africanas. ${ }^{49}$ Isso era particularmente visível no arquipélago de Cabo Verde. A este respeito, esse contexto insular de origem de Almada e Donelha, bem como base mercantil e retiro de Lemos Coelho (a partir de meados do século XVII), merece ser revisitado. A atitude negativa, além de uma apropriação dos preconceitos contra as "gentes de nação (hebraica)" difundidos, também, noutros espaços de presença portuguesa, talvez se possa explicar pelo constante labéu contra os cristãos-novos que atuavam na costa da Guiné e a rede de contratadores "da nação" responsabilizada pela decadência da ilha de Santiago.$^{50} \mathrm{O}$ conceito de cristão-velho era alvo

44 Sobre a conotação não racial coeva dos termos "raça" e "casta", ver: OLIVAL, Fernanda Olival. Rigor e interesses: os estatutos de limpeza de sangue em Portugal. Cadernos de Estudos Sefarditas, Lisboa, v.4, p.152, 2004; FIGUEIRÔA-REGO, João; OLIVAL, Fernanda. Cor da pele, distinções e cargos: Portugal e espaços atlânticos portugueses (séculos XVI a XVIII). Tempo, Niterói, v.16, n.30, 2011, p.137-138; CHAVES, Maria Eugénia Chaves. Race and caste: other words and other worlds. In: TORRES, Max S. Hering; MARTíNEZ, María Elena; NIRENBERG, David (eds.). Race and blood in the Iberian world. Zürich: Lit Verlag, 2012, p.39-58, p.56.

45 ALMADA. Tratado, p.11 e p.28. Usa-o noutros passos, sim, mas no sentido que daríamos, ou que corresponderia a, linhagem, tal como também o faz Lemos Coelho.

46 LEMOS COELHO. Descrição (1669), p.8 e p.9 (os grifos são nossos). As menções são tão numerosas, quer na descrição de 1669, quer na de 1684 que seria ocioso localizá-las em nota.

47 LEMOS COELHO. Discripção (1484), p.96 e p.102 (os grifos são nossos).

48 Arquivo Histórico Ultramarino (AHU), Conselho Ultramarino, Cód.39, fl.136.

49 Ver FIGUEIRÔA-REGO, João e OLIVAL, Fernanda. Cor da pele, distinções e cargos, p.130.

50 A este respeito veja-se TORRÃO, Maria Manuel Ferraz. Rotas comerciais, agentes económicos, meios de pagamento. In: Maria Emília Madeira Santos (coord.). História geral de Cabo Verde. v.II. Lisboa/Praia: Centro de Estudos 
de um interpretação adequada ao contexto sócio-histórico da ilha que coincidia com a menor severidade da legislação da limpeza de sangue sobre o sangue "gentio"51 (não muçulmano, nem judeu). É assim que Fernão Rodrigues da Silva escreve uma carta ao Rei de Portugal em 1655, em que se define como natural e morador de Santiago, "dos mais nobres daquella ilha e christão velho sem rassa de infecta nação", 52 é, por sua vez, definido por um anónimo como "mulato de Cabo Verde". ${ }^{53}$

Seja como for, os caracteres somáticos ou as origens incorretamente ditas raciais não eram cruciais para definir uma nação. Os autores valorizavam na descrição outros marcadores identitários, de acordo com o que observavam no terreno: o vestuário e o armamento ou formas de fazer a guerra. Eram relevantes porque faziam parte da (ou evocavam) a aparência exterior, o corpo cultural mencionado acima. Na impossibilidade de analisar os dois tópicos, o segundo com motivações subjacentes, não apenas para o comércio como o primeiro (os tecidos e panos contavam-se entre as moedas mais correntes das transações na Guiné), mas na natureza do relacionamento afro-português, mencione-se apenas o vestuário. O registro das formas de vestir, se mudavam de uma nação para outra, era considerado significativo. ${ }^{54}$ No entanto os autores encontraram mais semelhanças que dissemelhanças entre as nações quer na "guerra", quer no "trajo". Como se viu, a comparação entre nações vizinhas era sempre um importante processo de diferenciação. Um aspecto particular que poderia distinguir duas nações era a religião - serem ou não Muçulmanos ("Mouros", "da lei" ou "seita de Mafoma", "Mafometanos") ou "Gentios"/"Idólatras" (a categoria de representação corrente das religiões ditas tradicionais) ou, alguns deles, cristianizados. Também, como vimos no caso dos "juramentos", se um costume é específico ou caracteriza uma ou mais nações, tal é apontado. Mas numa região ainda minoritariamente islamizada, a religião, tal como as roupas, as armas e outros aspectos da cultura material eram representados como semelhantes ou quase iguais. $O$ comércio ou "trato", sempre presente nas descrições, mais que um marcador distintivo da identidade de nações - se bem que se registassem os produtos que umas e outras transacionavam - era-o da relação que cada uma delas estabelecia, ou não, com os portugueses.

Num programa de escrita etnográfica como o de Almada, seria de esperar que a língua se afigurasse uma categoria de informação mais eficaz

de História e Cartografia Antiga, Instituto de Investigação Científica e Tropical; Instituto Nacional da Cultura de Cabo Verde, 1995, p.17-123.

51 GREEN, Toby. Building creole identity in the African Atlantic; FIGUEIRÔA-RÊGO, João de; OLIVAL, Fernanda. Cor da pele, distinções e cargos, passim.

52 AHU, Cabo Verde, caixa 5, doc.35, fl. (1).

53 AHU, Cabo Verde, caixa 5, doc.36, de c. 20 de Abril de 1656

54 Ver ALMADA. Tratado, p.38, p.51, p.73, p.74, p.80, p.85 etc.; DONELHA. Descrição, p.98, p.102, p.110, p.134, p.148; LEMOS COELHO. Descrição (1669), p.8, p.43 (a predileção do autor vai para especificar o traje feminino), p.58 e os passos correspondentes na versão de 1684 
para distinguir nações. Porém, no Prólogo do Tratado, Almada já se confessava incapaz de escrever sobre a multiplicididade das "linguagens tão várias como os costumes diversos", e no decorrer do texto apenas nalguns casos se refere às particularidades e diferenças de língua entre as nações, quase sempre apenas constatando a existência dessas diferenças e na possibilidade de determinadas nações comunicarem entre si..$^{55} \mathrm{O}$ mesmo, mas ainda mais raramente, ocorreu nos outros tratados. Todavia, qualquer dos autores associa língua a "nação". Ouçamos Donelha, a propósito da Serra Leoa, tal como era concebida espacialmente na época dos autores: "Porque sem embargo que é povoada toda de diversas naçõis e diversas língoas, contudo se entendem e estão sojeitos aos Manes". ${ }^{56}$ Ou seja, para ele era claro aquilo que designaríamos hoje de espaço linguístico que, na época, seria coincidente com o espaço político, independentemente da diversidade das nações, de que as línguas próprias eram uma expressão. Esse espaço linguístico comum terá sido, possivelmente, a base da designação genérica de "Sapes" que nos levaria demasiado longe comentar.

Uma parte destes marcadores pode ser encontrada nas descrições portuguesas do início do século XVI e até nalguns relatos quatrocentistas de primeiro contato, mas muito longe da abundância e sistematicidade informativa dos tratados analisados. Para compreendermos o que nos chegou (e a forma como nos chegou) sobre as "nações" quer numas fontes, quer noutras é fundamental enunciar um problema prévio ao momento da redação. Os relatos são receptores de saberes de viajantes, como o foram os nossos autores, mas também dos seus indispensáveis mediadores mercantis locais. Entre eles contavam-se os marinheiros africanos que lhes serviam de línguas ou turgimãos (tradutores) e, a eles associados, os lançados que, na Guiné, eram portugueses que se "lançam (voluntariamente) com os Negros" (para usar a fórmula corrente na documentação oficial da época), uma migração ilegal na perspectiva da Coroa portuguesa, com o fim de comerciar livremente. De fato, residiam na região, organizavam-se em comunidades mestiças, frutos de casamentos mistos e em conjunto com os grumetes africanos, criando um grupo étnico luso-africano. A sua identidade foi construída em interação com as sociedades locais que os acolheram mas não deixaram de definir-se como "Portugueses". ${ }^{57}$ Tal significa que os marcadores identitários dos autores resultaram, potencialmente, de uma mistura com as formas de percepção da identidade dos próprios africanos e dos mediadores luso-africanos de ambos.

55 ALMADA. Tratado, p.11 e p.17 (Jalofos versus Fulas); p.29 (Barbacins versus Jalofos); p.60 (Jabundos, Banhuns e Cassangas); p.132 (Mandingas e Manes).

56 DONELHA. Descrição, p.98.

57 Sobre a construção identitária dos Luso-Africanos ou "Portugueses" e a sua evolução para o período deste estudo, a bibliografia é extensa. Alguma já foi citada na nota 30. Sublinhe-se ainda: BOULĖGUE, Jean. Les Luso-Africains de Sénégambie, XVIe-XIXe siècles. Lisboa: IICT/Université de Paris I-Centre de Recherches Africaines, 1989; BROOKS, George E. Eurafricans in Western Africa: commerce social status, gender, and religious observance from the Sixteenth to the Eighteeth Century. Athens/Oxford: Ohio University Press, James Currey, 2003. 
O marcador identitário mais importante, dir-se-ia mesmo decisivo, para definir uma "nação" era o nome ou dir-se-ia hoje, o etnônimo. Os viajantes e os comerciantes, desde os primeiros contatos pacíficos de meados do século XV em diante, teriam certamente uma primeira questão a colocar quando se encontravam com qualquer grupo de africanos: quem são vocês? Qual é o vosso nome? A prova que esta questão era efetivamente formulada é mostrada pela existência de etnônimos desde o relato do veneziano Alvise da Ca' da Mosto, ao qual se voltará adiante, passando pelo seu número crescente nas descrições do início do século XVI e sobretudo nas da nova sequência textual sobre a Guiné a partir de 1578.

Todavia, uma segunda questão, complementar à primeira, se impunha para viabilizar o comércio em terras totalmente controladas pelos africanos: quem é o vosso rei? quem manda nesta terra? Os dignitários políticos locais eram os únicos a autorizar todas as transações e a estabelecer as regras que os estrangeiros ou hóspedes vindos de fora deviam seguir. Este processo de conhecimento levou à recepção e apropriação de categorias africanas. Em primeiro lugar haveria uma apropriação de nomes locais como signos identificativos das "nações" às quais os africanos diziam ou consideravam pertencer. Nos tratados em causa neste estudo, o nome das "nações", a forma como eram nomeadas, foi um ponto de partida crucial para serem identificadas como tais. Se alguém se dizia Mandinka (Mandinga) - ou como tal era nomeado por um informante digno de fé - tal era aceite pelos viajantes-escritores como Almada e Donelha. Pelos mesmos anos da redação das suas obras, cujos informes dizem, porém, respeito às suas experiências guineenses da segunda metade do século XVI, a diferenciação entre um conceito lato de Mandinga, de uso corrente na região, e o conceito de Soninké, distinção que se justificaria, quer pela reivindicação pelos Mandingas de uma determinada origem (de "Mande Mansa", o distante grande dignitário do Mandé) que contrastaria com a local (na bacia do rio Gâmbia), quer a observância ou não da religião muçulmana, foi passada a escrito pela primeira vez pelo padre jesuíta Manuel Álvares na sua Ethiopia Menor (c. 1615) sob a forma de "Sonequeis". ${ }^{58}$ Colheu-a, provavelmente, junto dos informadores portugueses locais de que, além de uma versão do Tratado de Almada a que teve acesso, se socorreu para escrever a primeira parte da sua obra, respeitante a regiões que pouco frequentou. Quase sete décadas passadas, quando o texto de 1669 foi reescrito, Lemos Coelho também estabeleceu a mesma distinção confirmando os mesmos critérios de definição das duas "nações", mas testemunhando uma possível islamização dos Soninké: "A gente da terra são de nasção Sominques, mas pella

58 ÁLVARES, Padre Manuel. Etiópia Menor, manuscrito da Sociedade de Geografia de Lisboa, Res. 3 E-7, fls.8 e ss. Nesta obra o termo ocorre com algumas variantes ortográficas, as quais não sabemos se foram da responsabilidade do autor ou do copista setecentista. 
communicação grande que tem com estes Mandingas tem ja tomado todos a sua seyta e são mahometanos, mas com muitos erros". ${ }^{59}$ Este exemplo afigura-se significativo porque mostra a que ponto os autores estão próximos dos critérios africanos de definição da identidade, aceitando os processos mais comuns de auto-identificação das sociedades.

Em segundo lugar, desse questionário sobre designações de identidade resultou, nalguns casos, uma recepção do significado político africano dos grupos étnicos ou, ao menos, de uma identidade relevante para o grupo. A adopção de nomes como "Barbacins" e "Mandimanças" é um exemplo paradigmático, apesar da relevância dos dois nomes nos tratados ser muito distinta. Ela mostra, seja a apropriação de etnônimos locais, seja o que poderíamos designar por processo exterior de construção etnonímica a partir de concepções africanas de identificação de grupo. "Barbacins" era o nome dado pelos Portugueses aos Sereer do Bawol, do Siin e do Saalum, ${ }^{60}$ os três últimos termos correspondendo a nomes de unidades políticas que se situavam no Norte do atual Senegal (até ao rio Gâmbia). É um nome derivado de Buur-ba-Siin, que significa na língua wolof grande (ba) dignitário ou rei (buur) do Siin. ${ }^{61}$ A partir daqui é possível formular duas hipóteses interpretativas. A primeira, mais simples, um mero equívoco europeu tomando um nome de titular político pelo nome da população. ${ }^{62}$ Uma segunda hipótese parece fazer sentido: implicaria a recepção de um processo oeste-africano de etnogênese, no decorrer do qual um etnônimos e/ou uma identidade de grupo poderiam derivar do nome de um chefe ou dignitário ou mesmo de um espaço político. Assim sendo, uma das dimensões identitárias que unia o grupo emergia, perante uma pergunta do tipo "quem são vocês?" com uma resposta semelhante a "nós somos a gente do buur ba Siin", expressão simplificada e aportuguesada como "Barbacins" e depois ampliada, pelos viajantes, a grupos vizinhos representados como semelhantes. Nesta interpretação teríamos um etnônimos derivado de um processo de politogênese.

"Mandimanças" afigura-se um caso semelhante, mas é apenas usado uma vez e não seria a adaptação de um termo em uso pelos africanos. Foi inventado/recriado por Almada para, em justaposição sinonímica com Manes, ${ }^{63}$ expressar a ideia de que o traço principal dos últimos era a obe-

59 LEMOS COELHO. Discripção (1684), p.159. Como a versão de 1684 é uma reescrita profunda e acrescentada do texto de 1669 , a ponto de se poder considerar uma outra descrição, mas como, por outro lado, o autor não terá regressado à Guiné, é difícil saber se esta nova informação é datável da nova redação.

60 MOTA, Avelino Teixeira da. In: DONELHA. Descrição, n.194, p.274.

61 BOULĖGUE, Jean. Le Grand Jolof, p.16-17 e ss.

62 Segundo BOULĖGUE, Jean. Le Grand Jolof, p.16. Repare-se, contudo, que uma das abonações de Jean Boulègue é o relato de Diogo Gomes de Sintra, recentemente datado de c. 1484 (apesar de baseado nas memórias do viajante de meados do século) em que, no mesmo passo, usa, consciente disso, "Barbacins" como nome de povo e título político. Ver GOMES DE SINTRA, Diogo. Descobrimento primeiro da Guiné, edição (com novas restituição do texto latino original e tradução portuguesa) de NASCIMENTO, Aires A. Lisboa: Edições Colibri, 2002, p.88-89.

63 ALMADA. Tratado, p.132. 
diência ao "Mandimança" (de cuja terra, segundo ele, os Manes tinham chegado à Serra Leoa), como se viu acima, o dignitário do Mandé ou Mandi, o qual tanto ele quanto os outros autores da época afirmavam ser o grande "imperador dos Negros", testemunhando que muitas "nações" o reverenciavam. Por seu turno, Donelha, seguindo fontes africanas, esclarece que os nomes de duas "nações", os Mandingas e os Manes, provinham do de "Mandimansa":

Contam tantas grandezas e riquezas deste grande Mandimansa, que parece cousa impossível. O que eu sei é que antre as naçõis de todo o Guiné que têm desquerição e rezão, em nomeando Mandimansa tiram os barretes. Dizem que os Mandingas e Manes tomaram os tais nomes de Mandimansa. A sua principal cidade se chama Malem. Tenho falado com muitos Fulos, Jalofos, Mandingas em Guiné, e com muitos que se fizeram cristãos e nesta ilha se casaram, e todos de a maneira, sem desvariar, dizem deste Mandimansa as grandezas que tenho dito e muito mais. ${ }^{64}$

Se mais uma vez se verifica a origem endógena dos etnônimos, naturalmente adaptados ao português, também a pluralidade das fontes de origem africana da sua apropriação se constata. Além da diversidade de informadores que os autores dispunham na costa e nas ilhas, patente neste passo, note-se que a forma "Malem" é provavelmente de origem linguística fula, de "Malen" e não mandinga ${ }^{65}$ A referência de que a origem do etnônimos Mandingas e Manes (estes migrando para a Serra Leoa em meados do século XVI) na ligação ao Mandimansa, isto é, na família linguística mandinga significando o mansa ("rei") do Mandi (ou Mandé) confirma que a descrição de Donelha, tal com as outras, operava uma recepção dos processos regionais de etnogênese. Os homens identificavam-se com aqueles de quem dependiam numa cadeia, neste caso longa, de legitimidades. Em suma, as lógicas do discurso antropológico na identificação das nações são, neste caso, de origem africana.

\section{“Nações”, grupos étnicos: problemas de conceptualização his- toriográfica}

A análise da categoria de "nação" nas fontes tratadísticas europeias sobre a Senegâmbia dos séculos XVI e XVII conduz-nos a uma interpelação historiográfica fundamental no que respeita ao estudo das identidades africanas desta região: qual é a operatividade do conceito de grupo étnico e a relevância das

64 DONELHA. Descrição, p.120/122.

65 Informação pessoal do linguista Valentin Vydrine, a quem agradecemos. Já em 1972, Avelino Teixeira da Mota constatava a diversidade de origens africanas dos vocábulos retratando as mesmas realidades nos textos antigos, referindo influência fula na forma "Mallé" e "Malel". MOTA, Avelino Teixeira da. A África Ocidental em Os Lusíadas. Lisboa: Junta de Investigações do Ultramar, 1972, p.386-387. 
identidades étnicas? Este seria também um tema para um outro artigo mas, na sequência do que se disse antes, afigura-se incontornável enunciá-lo brevemente para futuras reflexões. Não vamos, por isso, aqui retomar a discussão que sobretudo foi suscitada a partir da já citada obra de Jean-Loup Amselle e de Elikia M'Bokolo, Ao coeur de l'ethnie. Diremos apenas que a contribuição de Amselle feita a partir da Antropologia é (ou deveria ser) um adquirido, no que toca à sua desconstrução de uma visão essencialista e rígida da identidade, em particular dos contornos étnicos, e a valorização alternativa de uma antropologia dos lugares a partir dos quais as sociedades se interconectam, dos diferentes tipos de espaços socializados, ou (como diriam os geógrafos) territórios, em que as sociedades africanas podem ser compreendidas nas suas relações. Dimensão que a utensilagem mental dos autores antigos nem sempre Ihes permitiu compreender. Aquilo que Amselle designa de antropologia dinamista valoriza a fluidez e flexibilidade da definição do sentimento de pertença ao grupo. Nesse sentido ela supera a conceptualização de Frederik Barth em "Ethnic Groups and boundaries", também já mencionada nas notas deste artigo, durante muito tempo um texto incontestado, que defendia que o grupo étnico se definia sobretudo pela afirmação das suas fronteiras em relação aos outros grupos. Amselle, em Logiques Métisses, vem recolocar a questão no seu devido lugar, mostrando que as identidades se negoceiam em função do contexto de relações de força em causa, a definição de uma dada cultura é a resultante de uma relação de forças intercultural. ${ }^{66}$ Assinalese que os exemplos de Amselle são em boa parte da região em foco neste artigo. Sobretudo Peter Mark, ao estudar a identidade dos "Portugueses" da Senegâmbia, vem mostrar como se podia construir uma identidade étnica que não excluísse a possibilidade da existência de identidades múltiplas, consoante o contexto das relações sociais em que um indivíduo se encontra. O autor destas linhas também defendeu a existência de identidades móveis (shifting identities) na região e aprofundou com Peter Mark esta perspectiva em The forgotten diaspora: Jewish communities in West Africa. Se em Au coeur de l'ethnie, Amselle reduz claramente as etnias a uma invenção colonial (entenda-se, como surgindo apenas no contexto da implantação do sistema colonial em África), recuou dessa posição radical no prefácio em co-autoria com M'Bokolo na reedição dessa obra em 1999. Antes deste prefácio, a historicidade do conceito de etnia mas também dos contornos e da vivência da realidade assim designada, em África, foram afirmados na obra dirigida por Jean-Pierre Chrétien e Gérard Prunier, Les Etnhies ont une Histoire, ${ }^{67}$ em parte em resposta a M'Bokolo e Amselle. Joseph Miller tem rejeitado como conceito operatório "grupos étnicos" e o que considerou ser uma alternativa politica-

66 AMSELLE, Jean-Loup. Mestizo Logics, p.33.

67 CHRÉTIEN, Jean-Pierre; PRUNIER, Gérard. Introduction. Dimension historique de l'ethnicité en Afrique. In: Les ethnies ont une histoire. Paris: Karthala/ACCT, 1989, p.8 (o grifo é nosso). 
mente correta, "etnicidades", entre vários outros conceitos que critica como "culturas" por "comunidades", em uso pelos antropólogos e historiadores que trabalham sobre a África, sobretudo a África antiga (para não falar em África "pré-colonial"), considerando que tais noções seriam estáticas e relevando de uma perspectiva ahistórica. ${ }^{68}$ Mais recentemente confirmou "étnico", "linguístico" ou "etno-linguístico" como eufemismos para o conceito ultrapassado de "tribo", como parte da tendência do discurso sobre a África para reconhecer os Africanos principalmente através desses conceitos. ${ }^{69}$ Esse debate já foi feito, como vimos acima, pela antropologia e historiografia francesas da segunda metade dos anos 1980, mas, na sequência do contributo de ruptura de Amselle, concorda-se com Miller, no sentido em que há ainda um longo caminho a percorrer para não centrar o objeto da História de África na etnias e na etnicidade e antes nas múltiplas conexões entre pessoas e comunidades, ${ }^{70}$ e espaços, em que ela deve ser pensada. Outra coisa diferente é rejeitar a existência da etnicidade como fenómeno social vivo e potencial alvo de análise histórica e cuja relevância varia segundo os contextos históricos concretos.

Tudo depende da forma como a etnicidade é conceitualizada. Joseph Miller valoriza o sentimento de pertença como o testemunho do caráter relativo da identidade, enquanto uma sensibilidade social fluida, socialmente contextualizada, ${ }^{71}$ perspectiva que este estudo partilha, como se mostrou, em resultado da desconstrução antropológica do objeto étnico colonial. Contudo, tal não é incompatível com a existência histórica de comunidades que se podem qualificar de étnicas. O próprio Miller no seu último livro usa recorrentemente (ora com aspas, ora sem aspas) o conceitos de "etnicidade" e "comunidade étnica" ou ainda o adjetivo "étnico". No seu pensamento estes aparecem agora como correspondendo a identidades coletivas que num dado momento foram criadas pelos africanos. ${ }^{72}$ Ouçamos Joseph Miller:

The creators of the early ethical (and eventually also ethnic) communities thereby extended truly ancient sentiments of parental and family attachment to political groupings manipulable historically, that is, in response to changing circumstances. They converted a primordial universal constant of human sentiment into a contingent historical strategy of forming political collectivities. ${ }^{73}$

E mais adiante:

68 MILLER, Joseph C. Presidential Address: History and Africa/Africa and History. American Historical Review, v.104, n.1, February,1999, p.1-32, p.15.

69 MILLER, Joseph C. Beyond blacks, bondage, and blame: why a multi-centric World History needs Africa. Historically Speaking, v.VI, n.2, p.7-30, p.8, nov./dez. 2004.

70 MILLER, Joseph C. Beyond blacks, bondage, and blame.

71 MILLER, Joseph C. Beyond blacks, bondage, and blame.

72 O próprio autor não é muito claro, ora afirmando terem essas identidades origem nos próprios africanos (p.46), ou serem de origem externa (p.83 e p.97): MILLER, Joseph C. The problem of slavery as History: a global approach. New Haven/London: Yale University Press, 2012, p.46, p.83, p.97.

73 MILLER, Joseph C. The problem of slavery as history, p.46. O itálico em "truly" é nosso. 
Slaving became one strategy among the many that Africans elaborated to develop and display the specific shared characteristics as markers of collective identities that colonial ethnographers later characterized as ethnic. That is to say "ethnic" or rather, since they were not inherent qualities but calculated strategies of historical differentiation, ethnicized stereotypes were designed to display uniformity and solidarity to outsiders. Performed homogeneity also masked the intrincal internal differentiation that held the group together around the mutually supportive relationships thus created. ${ }^{74}$

Não vou discutir, neste lugar, o perigo essencialista e ahistórico da concepção de identidade na dicotomia entre verdadeiro e falso nos termos em que o autor o coloca, nomeadamente para a África antiga como uma mera performance para uso externo. Miller, que é para todos nós, membros de uma comunidade mundial de historiadores que se interessam pela África, uma grande referência, seria o último a pretender esse resultado na sua estimulante interpelação ao nosso modo de fazer História. É, porém, dificilmente aceitável esta definição de "étnico" como um simples "estereótipo". Na verdade, tal seria negar aquilo que o mesmo autor defende: o caráter histórico das identidades coletivas e dos processos de apropriação identitárias, a esse nível, fruto de fenómenos de integração espacial de caráter político. Esses processos já foram estudados nas obras acima citadas, sobretudo para a África Ocidental entre os séculos IX e XVI, e conduziram a fenómenos de uniformização étnica, estimulada por uma politogênese, nem por isso menos assumida pelas sociedades. ${ }^{75}$ Veja-se o exemplo da construção de uma identidade mandinga alargada a partir da construção política maliana no século XIII.

Finalmente, Miller acaba por admitir, com reservas, a operatividade historiográfica do conceito de etnicidade e confirmar a existência de comunidades étnicas entre outras formas de identidades coletivas:

Ethnicity is useful historically only to designate contextualized strategies of creating communities efficacious not in excluding or exploiting others but in joining together situationally to seek the mutual benefits of complementarity differentiation (...) African cultivated individual diversity within multiple worlds that complementingly evoked - though only situationally, thus (again) historically - many specific ideological commonalities. Depending on immediate context, these ranged in scale from small lineages on through various residential and occupacional identities (...), to large abstract, anonymous ethnic collectivities mobilized for purposes of dealing with outsiders, including inquiring colonial-era ethnographers. ${ }^{76}$

As estratégias africanas de cultivar a diversidade de que fala Miller não fazem dessas comunidades étnicas ou grupos étnicos (a opção por um ou

\footnotetext{
74 MILLER, Joseph C. The problem of slavery as history, p.96.

75 Veja-se como no interior do Noroeste africano foi exemplificado o processo de transformações a que alude Miller: DIAKITÉ, Drissa. Unification étatique et processus ethniques: le cas des empires soudanais de l'âge d'or (VIle-XVle siècle). In: CHRÉTIEN, Jean-Pierre. e de PRUNIER, Gérard. (orgs.). Les ethnies ont une histoire, p.135-148.

76 MILLER, Joseph C. The problem of slavery as history, p.83-84.
} 
pelo outro termo é despicienda) menos parte desse processo. Uma etnicidade fluida não é menos importante para lidar com outsiders do que, por exemplo, alianças inter e supra-linhagísticas. ${ }^{77}$ Sem o cultivar da diversidade, juntamente com a flexibilidade, não seria possível compreender como é que o espaço em causa neste artigo funcionou como grande rede de comércio durante séculos. Reitere-se que as condições da "era colonial" não são idênticas às anteriores quanto à negociação das identidades.

Afigura-se-nos que é em casos concretos como aquele em que procuramos introduzir que é necessário definir e aferir as metodologias e conceitos operatórios. O que está em causa, na presente abordagem, não é a escoIha de um termo, de um significante; o mais vulgar na historiografia sobre África é, de fato, "grupo étnico", mesmo que tantas vezes empregue entre aspas, mais nas apresentações orais que nos textos publicados, mas sim a negação de designar uma realidade: o sentimento de pertença a um grupo, flexível, aberto, polissémico na sua interpretação e natureza e sobretudo histórico, em permanente transformação. Na região que se abordou, essas identidades, que à falta de melhor, designamos de étnicas, constituíram uma realidade, certamente fluida, para as populações. Assumir o termo épocal "nação" como conceito operatório em substituição de grupo étnico não resolve o problema ao nível de um discurso conceitualizado coerente. Antes de mais porque ele é uma representação europeia, mesmo que espelhando, pelo menos em parte, lógicas africanas, na sua aplicação, e que sofreu uma profunda evolução a partir do século XVIII. O que diríamos na história recente africana, no período das pós-independências, de prescindir do termo grupo étnico face ao diferente registro identitário que a nação constitui e que com ele indubitavelmente coexiste?

Por tudo o que se disse antes, não podíamos estar mais de acordo com George Brooks quando este sintetiza:

In short, western Africans opportunically redefine their identities in response to changing circumstances. Remote, even fictive, kinship ties, special bonds between groups such as "joking relationships", indeed any social or cultural advantages one can claim or contrive have for centuries facilitated human relationships and expedited trade, travel, migration, and settlement in western Africa. ${ }^{78}$

Porém, não compreendemos que, em sequência, afirme que as identidades (étnicas) que muitos indivíduos e grupos "may have claimed in the past are speculative". Tal seria, novamente, defender uma concepção essencialista da identidade, como se esta não fosse verdadeira ou real, num dado contexto,

77 Veja-se, nesse sentido, a abordagem na longa duração (na história antiga e recente para uma mesma região) de FORREST, Joshua. Lineages of State fragility: rural civil society in Guinea-Bissau. Oxford/Athens: James Currey/ Ohio University Press, 2003.

78 BROOKS, George E. Landlords and strangers, p.28. 
para quem a reclama. É, evidentemente difícil, estabelecer a fronteira entre o que era um signo identificativo próprio ou com origem, ainda que indireta, local e uma simples apropriação africana de um signo vindo de fora. Tal é certamente mais fácil de mostrar num outro contexto histórico, o da implantação do sistema colonial, em que a classificação étnica fez parte das práticas administrativas, como Amselle e Miller lembram. Mas temos muitas dúvidas de que os "ethnographers" (o termo é de Brooks), no caso aqueles com que trabalhamos, dos séculos XVI e XVII, tivessem condições para conduzir tal operação. Outra questão é a natureza dos grupos por eles nomeados. Para Brooks seriam muito provavelmente aglomerados de famílias alargadas e clãs habitando vastas áreas do noroeste africano, para além dos que considera como exceções, alguns grupos ocupacionais e populações vivendo em áreas de estados fortemente centralizados. ${ }^{79}$ Não se dispõe de espaço para discutir caso a caso, como merecia, a natureza, no espaço e no tempo, desses grupos considerados "nações" pelos autores. Mas não se deixa de reparar que, implicitamente ou explicitamente, o autor admite que os grupos existiam e tinham (ou eram-lhes dados) nomes. O único critério de nomeação de grupos com que Brooks aceita trabalhar na sua obra - Landlords and strangers que é, aliás, um texto de referência da historiografia da Western Africa - é o de base linguística, o que nos parece redutor face à massa informativa antropológica dos textos da época sobre eles, mesmo tendo em conta que o mesmo etnônimo podia corresponder a sentimentos de pertença identitária totalmente diferentes, quer numa mesma época, quer e ao longo do tempo. ${ }^{80}$ No entanto, não deixa de ser curioso que a língua seja precisamente um dos marcadores identitários distintivos de "nações" transversais aos autores que se abordaram. Também não acompanhamos Toby Green, que, num importante livro, segue uma linha de raciocínio semelhante à de Brooks, quando afirma:

It becomes clear that lineage, and not some form of proto-ethnic identity, matters most here when we recall that the very names which the Portuguese used to denote the peoples of the region were themselves projections. (...) early communication between Africans and the Portuguese was carried out using the Mandinka as intermediaries and shared language of Arabic, which some Mandinka and Portuguese held in common. This being the case, the names by which the Portuguese learnt to call the peoples of the region were likely imparted to them by the Mandinka, a hypothesis substantiated by the fact that many of these names are Mandinka in origin. ${ }^{81}$

Se concordamos com Green quando diz que as conexões de linhagem e de parentesco eram fundamentais para a forma como as pessoas se

79 Sigo quase à letra as formulações de BROOKS, George E. Landlords and Strangers, p.28.

80 Tal não desvaloriza a importância das conclusões de HAIR, P. E. H. Ethnolinguistic continuity on the Guinea Coast. In: Africa encountered: European contacts and evidence. 1450-1700. Aldershot: Variorum, 1997, VII, p.247-269.

81 GREEN, Toby. The rise of the Trans-Atlantic slave trade, p.62-63. 
relacionavam entre si, ${ }^{82}$ já não o ratificamos quando formula a hipótese de os nomes usados pelos portugueses para designar as populações serem uma simples projeção fruto de uma invenção anterior, mandinga. Não há evidência de que o comércio iniciado na costa do norte do atual Senegal a partir do final dos anos 40 do século XV tivesse já intermediários mandingas. Alvise da Ca'da Mosto (ou, por facilidade, Luís de Cadamosto na tradução portuguesa do seu nome) testemunha-no, nas Navigazioni, quando retrata relações anteriores diretas dos portugueses com os dignitários da costa, nomeadamente com o dame/ do Kajoor ${ }^{83}$ e se refere, ao relatar os primeiros contatos (não pacíficos) no Rio Gâmbia em 1455, às relações comerciais que os portugueses já mantinham como os Wolof do Reino de Senega (Grão-Jolof). ${ }^{84}$ Não é por acaso que termos como ziloffi (Wolof), barbacinj (Barbacins) e sereri (Sereer) aparecem no seu relato, ${ }^{85}$ fruto de recolha direta ou reminiscência provável de informações portuguesas, anteriores aos contatos com os mercadores mandingas ou mandé em geral, da região do mesmo rio Gâmbia. Estes primeiros contatos mercantis foram conduzidos através de turgimãos ou línguas, escravos wolof que aprendiam o português e eram cristianizados ${ }^{86}$ e não necessariamente falantes de árabe. No decorrer do século XVI, a estratégia dos portugueses e seus descendentes luso-africanos que se instalaram na Guiné foi a de difundir, informalmente, o português como língua de comunicação do comércio, o que se tornou uma realidade a par do Mandinga que já o era, e de usar outras línguas locais com recurso a tradutores. ${ }^{87}$ Os seus principais informantes sobre as populações dos rios de Guiné eram os grumetes africanos que com eles viviam e comerciavam pelos rios acima, sobretudo oriundos de grupos costeiros como os papel e os biafadas e não necessariamente os mandingas que conduziam os seus negócios numa relação dual de rivalidade/parceria com os membros do grupo luso-africano. Estes residentes na costa contam-se, por sua vez, entre os principais informadores dos mercadores/escritores que, com eles, frequentavam os rios. Se a relação luso-mandinga foi indubitavelmente intensa, baseada num interesse comum mercantil, ela poderá ter deixado traços na nomeação de certos grupos como os Banhuns e os

82 GREEN, Toby. The rise of the Trans-Atlantic slave trade, p.62.

83 O duplo título do dignitário - geral e específico da unidade política do Kajoor (Buur+damel) - aparece na forma budumel no autor quatrocentista. CADAMOSTO, Luís de. Viagens de Luís de Cadamosto e de Pedro de Sintra. estabelecimento do texto italiano e trad. de João Franco Machado. 2 ed. Lisboa: Academia Portuguesa da História, 1988, p.34-124. Escolheu-se esta edição porque publica o manuscrito italiano (em dialeto véneto) de Da Mosto mais próximo da escrita do autor, c. 1463, e das suas viagens. A tradução portuguesa tem, em contrapartida algumas falhas e foi confrontada com o texto italiano.

84 CADAMOSTO, Luís. de. Viagens, p.57/154.

85 CADAMOSTO, Luís. de. Viagens, p.28-29/147.

86 CADAMOSTO, Luís. de. Viagens, p.148.

87 HAIR, P. E. H. The use of African languages in Afro-European contacts in Guinea: 1440-1560. Sierra Leone Language Review. v.5, p.5-26, 1966. 
Cassanga ${ }^{88}$ ou na distinção entre Mandingas e Soniké, mas outros são fruto de uma simples adaptação ao português de vocábulos de outras línguas como explicita António Carreira. ${ }^{89}$ Mesmo para o Mandé, coração do espaço político e cultural de que provinham os Mandingas, distante da costa, as fontes de informação poderiam ser diversificadas como se comprovou pelo exemplo de Donelha acima citado. Também por isso a nomeação das "nações" não estavam isentas de confusões, mas não se pode fazer tábua rasa de um etnônimos que, nos textos, muda no tempo e muito menos tomar por bom que o uso africano do mesmo etnônimos corresponde à mesma definição de identidade.

Para os séculos XVI e XVII, de forma alguma se podem considerar os portugueses como uma das "powerful forces" colaborando em conjunto para nomear os povos da região. Não vou discutir neste lugar a problemática da mandinguização, mas os portugueses certamente não foram uma força poderosa, dependente como estavam das regras definidas pelos donos da terra, africanos para lá residirem: eram hóspedes em terra alheia. ${ }^{90}$ Considera-se dificilmente sustentável que a identidade "étnica" dos grupos fosse uma simples invenção e depois imposição ocidental, para o período em foco. Os exemplos, dados acima, diretamente colhidos na análise das fontes, tornam problemática essa generalização. Permitem sim pensar que, em muitas situações, os critérios de pertença identitária que aparecem refletidos nos etnônimos das fontes portuguesas eram marcados pelo sentimento local de coesão por ligação a um dignitário, por exemplo, nas regiões de influência wolof, a um buur, no caso do que os portugueses designaram

88 Diferentemente do que afirma GREEN, Toby. The rise of the Trans-Atlantic slave trade, p.63, Teixeira da Mota, o autor base da sua argumentação, não afirma como hipótese que muitos etnónimos fossem mandingas na sua origem, dado que, falando, aliás, apenas da "Guiné Portuguesa" do seu tempo, tem o cuidado de destrinçar as origens das denominações dos textos antigos quando as encontra; neste caso a sua teoria aplicar-se-se-ia apenas aos Banhuns e Cassangas. Ver MOTA, Avelino Teixeira da Mota. Guiné Portuguesa. v.l, (Lisboa): Agência Geral do Ultramar, 1954, p.144-145.

89 CARREIRA, António. O fundamento dos etnônimos na Guiné Portuguesa. Garcia de Orta, Lisboa, v.10, n.2, p.305323, 1962. O autor que, como Teixeira da Mota, trata da então Guiné Portuguesa, recorre abundantemente à origem nas fontes que analisamos, sintetiza a questão de uma forma equilibrada: "Regra geral, a formação de topónimos (antropônimos e etnônimos) faz-se com um ou mais elementos da própria língua dos povos de cada região e por sua iniciativa; ou com um ou mais elementos (mas de uma só língua) dos falantes de povos vizinhos ou dominantes do ponto de vista cultural, por iniciativa própria ou alheia. Nesta última hipótese, quase sempre a iniciativa pertence a estranhos e o vocábulo ou vocábulos assim formados passam a ter aceitação geral, quer no meio de que procedem, quer naquele em que são aplicados, em face do uso constante e generalizado" (p.322).

90 A historiografia é prolífica a este respeito. Vejam-se, por muitos outros: BROOKS, George E. Landlords and strangers; BROOKS, George E. Landlords and strangers: ecology, society, and trade in Western Africa, 1000-1630. Boulder, Westview Press, 1993; CARREIRA, António, este com ampla evidência documental da fragilidade da presença portuguesa na região. CARREIRA, António. Os Portugueses nos Rios de Guiné. Lisboa: (Ed. do Autor), 1984, p.8 e sobretudo CARREIRA, António. Documentos para a História das ilhas de Cabo Verde e "Rios de Guiné" (Séculos XVII e XVIII). Lisboa: (Ed. do Autor), 1983, p.28-9. Dos limites impostos pelas sociedades africanas à vivência e processos de identificação dos "Portugueses" residentes na Guiné, ver também SOARES, Maria João Soares. Para uma compreensão dos Lançados nos Rios de Guiné. Século XVI - meados do século XVII. Studia, n.56/57, p.147-222, 2000; HORTA, José da Silva. Ser 'Português' em terras de Africanos. Não faz, por isso sentido incluir, para o caso da Guiné do Cabo Verde, os Portugueses entre as "Powerful and expansionist societies (que) have often found itself useful to classify their foreign subjects, and such classification is of its nature artificial"; GREEN, Toby. The rise of the Trans-Atlantic slave trade, p.63. 
por Barbacins, ou mesmo eventualmente os "Jalofos" ao buur-ba-Jolof, ${ }^{91}$ o que claramente nos remete, ao contrário do que afirmam Brooks e Green, para um critério supra linhagístico ou acima do parentesco e antes para um critério político. Neste, o poder é definido não pela vastidão do território mas segundo o poder sobre os homens reconhecido por uma comunidade, esse sim, a um determinado nível, ramificado e negociado a partir da lógica das linhagens e do parentesco. Outros etnônimos relacionavam-se, por exemplo, com o nome da região contatada, criados ou não pelos portugueses "práticos" dos rios ou reproduzindo os nomes usados localmente, mas não é possível esgotar aqui a questão.

Termino atravessando, sem pretensões, fronteiras oceânicas. Na sua obra sobre as origens do Candomblé jeje na Bahia, Luis Nicolau Parés, na sequência da discussão da natureza das "nações" de origem africana pela historiografia brasileira (e hispano-americana), acompanha, desde o golfo da Guiné, a metamorfose de "jeje" de grupo étnico minoritário em "denominação metaétnica" (retomando Jesús Guanche Pérez), para significar uma designação que passou a incluir uma pluralidade de grupos étnicos devido ao tráfico de escravos..$^{92} \mathrm{Um}$ caso diferente do primeiro, mas tendo em comum a pluralidade étnica que esconde, é a recorrência dos signos "minas", "angolas", "moçambiques" etc. na documentação escravista, geralmente ligada, como é bem sabido, aos portos de embarque, mas também sujeitas a metamorfoses próprias na África e nas Américas. Apenas chamo a atenção para um contraste: nas listas e inventários de escravos oriundos da mesma grande região, a Senegâmbia ou Guiné do Cabo Verde, em que figuram categorias que tinham também como referência portos de embarque como "Argui" (Arguim), desde o século XVI, mais tarde "Cacheu", "Bissau" ou "Geba", por exemplo, figuram também designações, bem mais numerosas. À falta de melhor - tal como falei em comunidades ou grupos étnicos e em identidades étnicas -, direi etnônimos, como os historiadores que as compilaram, muitas deles mencionados nos três tratados. Tendo em conta a cronologia dos tratados, vou seguir um quadro elaborado por David Wheat, a partir de apenas três viagens para as Caraíbas espanholas, respectivamente de 1572, 1575 e 1634: os termos que ocorrem, com variantes ortográficas, são os seguintes: "ariata", "balanta", "bañon", "baoyote", "berbecin", "biafara", "Bijago", "Brame" (Papel), "Casanga", "Folupo", "Jolofo", "Mandinga" "Nalu", "Sape", "Baga", "Cocoli", Landima", "Linba", "Soso" etc. ${ }^{93}$ Deixo uma interrogação: deverão ser estes termos encarados como simples invenções escravocratas ou

91 Ver BOULÈGUE, Jean. Le Grand Jolof, p.16-17 e ss

92 PARÉS, Luís Nicolau. A formação do Candomblé: história e ritual da nação jeje na Bahia. 2 ed. rev. Campinas: UNICAMP, 2007, p.30.

93 Ver WHEAT, David. Atlantic Africa and the Spanish Caribbean, 1570-1640. cap.1, Table 1. Agradeço ao autor o acesso a este capítulo do texto da sua tese de doutoramento em vias de publicação. 
antes como categorias que, direta ou indiretamente, refletem identidades africanas? ${ }^{94} \mathrm{O}$ seu destino no Novo Mundo seria o tema de outro artigo e certamente de um outro autor. ${ }^{95}$

\section{Greater Senegambia/ Guiné do Cabo Verde in Western Africa}

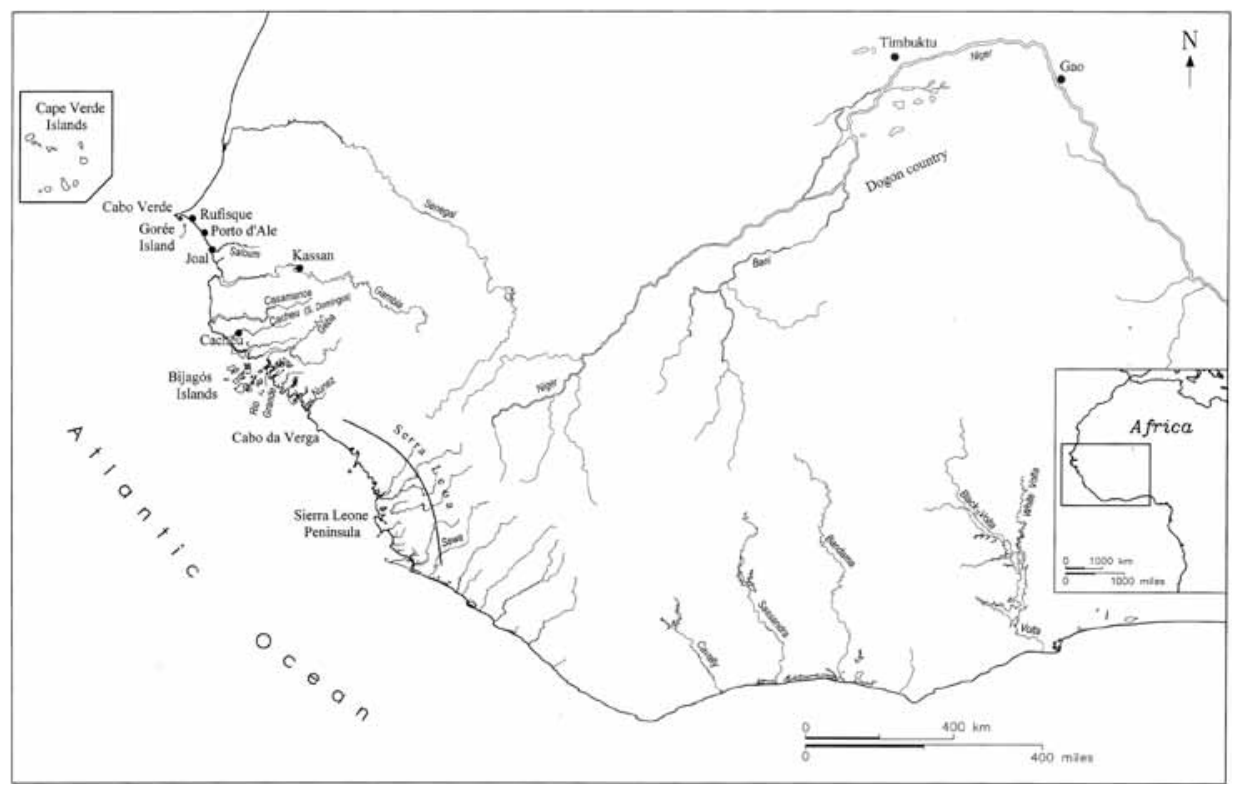

Mapa 1. "A Grande Senegâmbia/Guiné do Cabo Verde no Noroeste Africano". In: MARK, Peter e HORTA, J. da Silva. The Forgotten Diaspora: Jewish Communities in West Africa and the Making of the Atlantic World. Cambridge: Cambridge University Press, 2011. Mapa de Peter Mark e de José da Silva Horta.

94 Tendo em conta os tratados analisados, o mero exemplo entre muitos dos etnónimos do quadro referido e as evidências colhidas na obra de Walter Hawthorne citada na nota seguinte, para os escravos vindos dos portos da Senegâmbia para a Amazônia, em números esmagadores, não é possível concordar com a generalização de Joseph Miller, segundo a qual "African ethnicities in the Americas related more to the various ports along the African coast where they had entered the commercial world of the Atlantic, often buillding on broadly shared linguistic backgrounds in the regions from where they come, than to other communities in which they had previously lived." MILLER, Joseph C. The problem of slavery as History, p.152.

95 A título exemplificativo do espaço brasileiro, veja-se a forma notável como Vanicléia Silva Santos desconstrói a ligação a uma etnicidade mandinga da bolsa com o mesmo nome e dos seus produtores: SANTOS, Vanicléia Silva. Mandingueiro não é Mandinga: o debate entre nação, etnia e outras denominações atribuídas aos africanos no contexto do tráfico. In: PAIVA, Eduardo França; SANTOS, Vanicléia Silva (org.). África e Brasil no mundo moderno. São Paulo: Annablume, 2012, v.1, p.11-27 ou, por contraste de situações, a análise de Walter Hawthorne das continuidades identitárias guineenses na Amazónia da segunda metade do século XVIII e inícios do século XIX; HAWTHORNE, Walter. From Africa to Brazil: culture, identity and Atlantic slave trade, 1600-1830. Cambridge: Cambridge University Press, 2010. 
Political map of Northern Senegambia and Guinea-Bissau region in the $17^{\text {th }}$ century

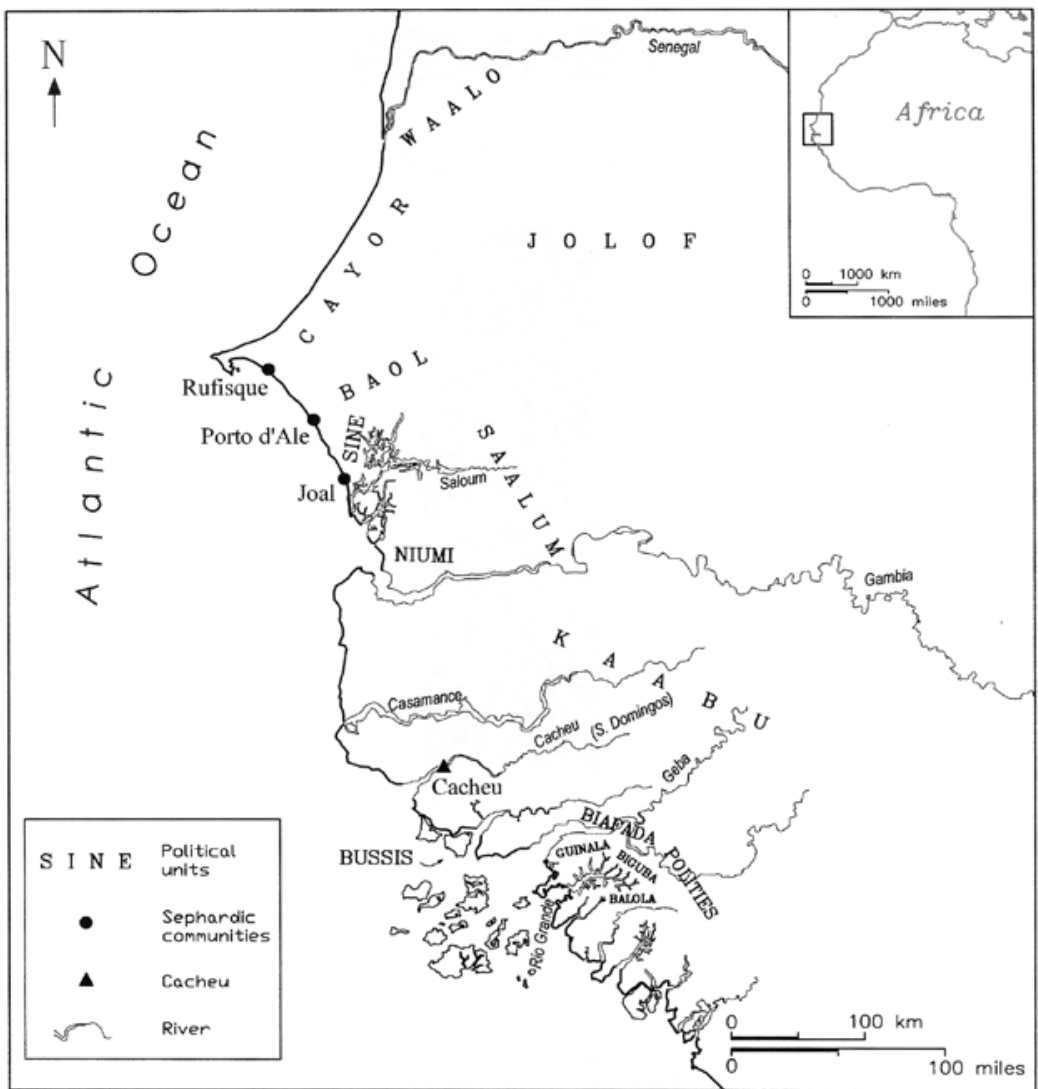

Mapa 2. "Mapa político da Senegâmbia setentrional e da região da Guiné-Bissau no século XVII". In: MARK, Peter e HORTA, J. da Silva. The Forgotten Diaspora: Jewish Communities in West Africa and the Making of the Atlantic World. Cambridge: Cambridge University Press, 2011. Mapa de Peter Mark e de José da Silva Horta. 